\title{
Detection of white spot baculovirus (WSBV) in giant freshwater prawn, Macrobrachium rosenbergii, using polymerase chain reaction
}

\author{
S.E. Peng ${ }^{\text {a }}$, C.F. Lo ${ }^{\text {a }}$, C.H. Ho ${ }^{\text {a }}$, C.F. Chang ${ }^{\text {b }}$, G.H. Kou ${ }^{\text {a, * }}$ \\ ${ }^{a}$ Department of Zoology, National Taiwan University, Taipei, Taiwan, ROC \\ ${ }^{\mathrm{b}}$ Tung Kang Marine Laboratory, Taiwan Fisheries Research Institute, Tung Kang, Ping Tung, Taiwan, ROC
}

\begin{abstract}
White spot baculovirus (WSBV) is the causative agent of a disease which decimated some cultured penaeid shrimp populations and inflicted severe economic damage in Taiwan. Until very recently, the giant freshwater prawn Macrobrachium rosenbergii was thought to be unaffected by this virus, but now signs closely resembling white spot syndrome (WSS) have been observed on its exoskeleton. In this paper, WSBV was established as the causative agent by using the diagnostic polymerase chain reaction (PCR) with WSBV-specific primers. WSBV was found in $M$. rosenbergii larvae, postlarvae, juveniles, and adults. The amplified product from the DNA of the naturally-infected WSS $M$. rosenbergii was similar to that of WSBV-infected Penaeus monodon. Furthermore, comparison of the restriction profiles of these two PCR products by HaeIII, HpaII, RsaI, and Sau3AI revealed no differences, suggesting that WSBVs from the infected $P$. monodon and $M$. rosenbergii are closely related, if not identical. A homogenate positive in one-step WSBV diagnostic PCR was prepared from frozen $P$. monodon for the challenge experiment. Dilutions were added to tanks of healthy $M$. rosenbergii larvae and postlarvae. After 2 days, some of the dead specimens were positive for WSBV by diagnostic PCR. (C) 1998 Elsevier Science B.V. All rights reserved.
\end{abstract}

Keywords: White spot syndrome (WSS); White spot baculovirus (WSBV); WSBV diagnostic PCR; Macrobrachium rosenbergii

\section{Introduction}

White spot baculovirus (WSBV) (Lightner, 1996) is the causative agent of a new viral disease which has caused high shrimp mortality and severe damage to the shrimp

\footnotetext{
* Corresponding author. Fax: + 886-2-23638179; e-mail: ghkou@ccms.ntu.edu.tw.
} 
culture industry in Taiwan (Chou et al., 1995; Wang et al., 1995). Since 1992, viral diseases have reduced the production of cultured marine shrimp to 40-70\% of 1992 production levels (Fisheries Yearbook of Taiwan Area, 1992-1995). The most obvious sign of this viral disease is the appearance of white spots in the exoskeleton of diseased shrimp. Similar diseases have been reported in other Asian countries, and various causative pathological agents have been noted. For example, there is the rod-shaped nuclear virus of Penaeus japonicus (RV-PJ) in Japan (Inouye et al., 1994; Momoyama et al., 1994; Nakano et al., 1994; Takahashi et al., 1994), hypodermal and hematopoietic necrosis baculovirus (HHNBV) in China (Cai et al., 1995) and systemic ectodermal and mesodermal baculovirus (SEMBV) in Thailand (Wongteerasupaya et al., 1995). Despite the different names, all of these viruses cause white spots on shrimp exoskeleton and have similar histologies.

Based on the genomic library of WSBV, a cloned WSBV DNA fragment was sequenced and specific primers were designed to detect WSBV infection in penaeid shrimp (Lo et al., 1996a). The organotropism of WSBV was studied by in situ hybridization and diagnostic PCR (Lo et al., 1996a; Chang et al., 1996). The host range and native potential vectors or carriers of WSBV are also being investigated. WSBV can be detected in a wide range of crustaceans found in shrimp culture ponds and even in those caught from the sea (Lo et al., 1996a,b).

The giant freshwater prawn, Macrobrachium rosenbergii, is an important cultured species in Taiwan. Recently, Lo et al. (1996b) discovered it exhibits the white spot syndrome (WSS). Although serious mortality associated with WSBV has not been reported, understanding the pathological effect of WSBV in freshwater prawns may help reduce the incidence of WSS. This study therefore determines whether WSBV is the causative agent of WSS in giant freshwater prawn, M. rosenbergii, by diagnostic PCR and by challenge experiments.

\section{Materials and methods}

\subsection{Animals}

Grossly normal $M$. rosenbergii at various life stages were obtained from six individual culture or hatchery farms (I-VI) in southern Taiwan. The juveniles and adults collected from farms I to $\mathrm{V}$ weighed 2 to $40 \mathrm{~g}$. Postlarvae and larvae with opaque musculature syndrome were taken from farm VI. For the challenge experiments, the larvae and postlarvae were collected from another hatchery. The challenge experiments were performed at the Tung Kang Marine Laboratory of the Taiwan Fisheries Research Institute in Ping Tung Prefecture (southern Taiwan). Before the challenge experiments, samples of the larvae and postlarvae were tested by two-step WSBV diagnostic PCR (Lo et al., 1996b) to confirm that they were negative for WSBV. The postlarvae were cultured in fresh water and the larvae were cultured in $25 \%$ o brackish water.

Diseased $P$. monodon and $M$. rosenbergii were collected from culture farms in southern Taiwan. The carapaces were removed and observed with a differential interference microscope (Axiovert 135, DIC Zeiss, Germany). 


\subsection{Preparation of shrimp DNA for WSBV diagnostic PCR}

Either whole postlarvae and larvae or a pereiopod (approx. $100 \mathrm{mg}$ ) removed from an adult specimen were placed in individual microfuge tubes and frozen rapidly in liquid nitrogen. They were then stored at $-70^{\circ} \mathrm{C}$ until use for DNA preparation. Shrimp DNA was isolated following the method described by Lo et al. (1996a,b) with some modification. Briefly, a digestion buffer $(100 \mathrm{mM} \mathrm{NaCl} ; 10 \mathrm{mM}$ Tris- $\mathrm{HCl}, \mathrm{pH} 8 ; 25$ mM EDTA, pH 8, 0.5\% $N$-lauryl sarcosine, $0.5 \mathrm{mg} / \mathrm{ml}$ proteinase K) was added to each microfuge tube (200 $\mu \mathrm{l}$ for postlarval and larval samples and $1.2 \mathrm{ml}$ for pereiopod samples). The tissue in the tube was then crushed with a disposable stick. After $1 \mathrm{~h}$ incubation at $65^{\circ} \mathrm{C}, 5 \mathrm{M} \mathrm{NaCl}$ was added to the DNA solution until it reached $0.7 \mathrm{M}$. This preparation was then treated with $1 \% N$-cetyl $N, N, N$-trimethylammonium bromide (CTAB) for $10 \mathrm{~min}$ at $65^{\circ} \mathrm{C}$ after which it was extracted with $1 \times$ volume of chloroform/isoamyl alcohol once, $1 \times$ volume of phenol 2 to 3 times, and $2 \times$ volume of chloroform/isoamyl alcohol once. The DNA was recovered by ethanol precipitation and dried. Finally, the DNA was resuspended in $0.1 \times$ TE buffer and incubated in a water bath at $65^{\circ} \mathrm{C}$ for $30 \mathrm{~min}$, before being stored at $4^{\circ} \mathrm{C}$ until used.

\subsection{WSBV diagnostic PCR}

Diagnostic PCR for WSBV was carried out as described by Lo et al. (1996a,b) using the following primer sets: 146F1, 5'-ACT ACT AAC TTC AGC CTA TCT AG-3'; 146R1, 5'-TAA TGC GGG TGT AAT GTT CTT ACG A-3'. For two-step WSBV diagnostic PCR, the internal primers, 146F2, 5'-GTA ACT GCC CCT TCC ATC TCC A-3', and 146R2, 5'-TAC GGC AGC TGC TGC ACC TTG T-3', were utilized as described by Lo et al. (1996a). This two-step nested PCR is $10^{3}-10^{4}$ times more sensitive than one-step PCR and its high sensitivity and specificity enable detection of latent or pre-latent WSBV in shrimp.

The quality of DNA extracted from test organisms was checked with a primer set amplifying a conserved decapod ribosomal RNA gene fragment (Lo et al., 1996a) before application of WSBV diagnostic PCR. The two primers used were 143F (5'-TGC CTT ATC AGC TNT CGA TTG TAG-3', where $N$ represents $\mathrm{G}, \mathrm{A}, \mathrm{T}$ or C) and $145 \mathrm{R}$ (5'-TTC AGN TTT GCA ACC ATA CTT CCC-3').

For one-step WSBV diagnostic PCR, $0.1 \mu \mathrm{g}$ DNA in a $100-\mu 1$ reaction mixture was used. For two-step PCR, $10 \mu \mathrm{l}$ of the first-step reaction mixture was added to $90 \mu \mathrm{l}$ of the PCR cocktail and the reactions were carried out as described by Lo et al. (1996a).

\subsection{Comparison of restriction profiles of products from two-step PCR amplification}

The positive products of two-step WSBV diagnostic PCR were recovered by ethanol precipitation and further digested with HaeIII, HpaII, RsaI and Sau3AI restriction endonucleases. The results were analyzed by electrophoresis on $1.5 \%$ agarose gel containing ethidium bromide at $0.5 \mu \mathrm{g} / \mathrm{ml}$, and visualized by ultraviolet transillumination. 


\subsection{WSBV challenge in Macrobrachium rosenbergii}

For challenge experiments, postlarvae and larvae were placed in 2-liter aquaria containing $1800 \mathrm{ml}$ aerated, coral sand-filtered fresh water (postlarvae) or 25\% brackish water (larvae) at room temperature $\left(23-26^{\circ} \mathrm{C}\right)$. They were acclimated for 1 day prior to testing. Approximately 50 specimens were placed in each aquarium and 1 group comprised 5 tanks (20 tanks total for 4 groups). During the 9-day experimental period, all animals were fed with a commercial diet 3 times daily $(0.03 \mathrm{~g} /$ feeding $/$ tank $)$. A piece of black plastic net (1 mm mesh) was hung in each aquarium as a shelter. The live shrimp usually attached themselves to the net while moribund individuals fell to the bottom. Moribund shrimp specimens were collected daily and the extent of WSBV infection was assessed by diagnostic PCR.

The exoskeleton and muscle $(5 \mathrm{~g})$ were removed from frozen naturally diseased giant black tiger shrimp ( $P$. monodon) which were positive for WSBV by one-step diagnostic PCR. These were homogenized in $140 \mathrm{ml}$ cold $33 \%$ seawater by polytrone. After removing large debris, $12 \mathrm{ml}$ of the homogenate was added to one group of 5 larval aquaria and one group of 5 postlarval aquaria. After $11 \mathrm{~h}, 1200 \mathrm{ml}$ of water was removed from each aquarium and replaced by clean brackish or fresh water as appropriate.

\subsection{Control groups}

To each tank in the larval ( 5 tanks) and postlarval (5 tanks) control groups was added $12 \mathrm{ml}$ homogenate prepared from the exoskeleton and muscle of shrimp that tested negative for WSBV by PCR. After $11 \mathrm{~h}$, water was replaced like the treated groups.

\subsection{Southern hybridization of one-step WSBV diagnostic PCR products}

Dead larvae and postlarvae were collected 48-h post-exposure to WSBV homogenate from P. monodon. They were subjected to one-step WSBV diagnostic PCR, after which the PCR products were subjected to electrophoresis. The gel used for analysis was then immersed in alkali solution ( $1.5 \mathrm{M} \mathrm{NaCl}-0.5 \mathrm{~N} \mathrm{NaOH})$ to denature the DNA in the gel before it was neutralized with $1 \mathrm{M}$ Tris $(\mathrm{pH}$ 7.4) and $1.5 \mathrm{M} \mathrm{NaCl}$, and transferred to a Hybond-N nylon membrane using a vacuum transfer unit (Hoefer TE 80) for 60 min. Following Sambrook et al. (1989), $20 \times \mathrm{SSC}(3 \mathrm{M} \mathrm{NaCl}, 0.3 \mathrm{M}$ Sodium Citrate) was used as transfer buffer. The blot was used for hybridization with a DIG-labelled WSBV specific probe derived from the 941 bp PCR product.

\section{Results}

\subsection{Comparison of white spot syndrome of P. monodon and M. rosenbergii}

$P$. monodon naturally infected with WSBV and $M$. rosenbergii with WSS are shown in Fig. 1A,B, respectively. The white spots are much more easily seen on P. monodon. 

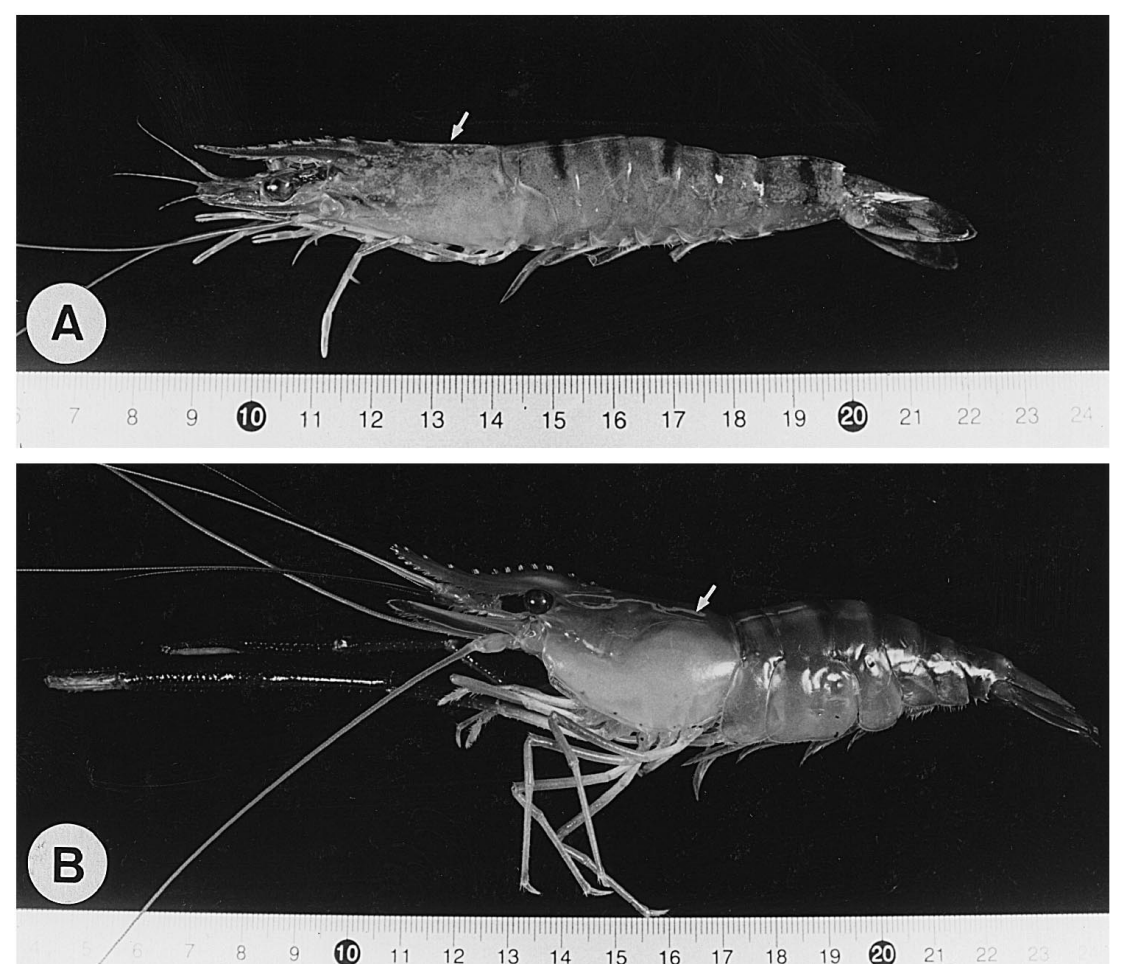

Fig. 1. Cultured marine shrimp P. monodon (A) and freshwater prawn M. rosenbergii (B) displaying white spot syndrome. The white spots are easily seen in P. monodon but not in $M$. rosenbergii. Scale bar: $1 \mathrm{~cm}$.

The size of the white spots in the carapace of $M$. rosenbergii was less than $0.5 \mathrm{~mm}$ in diameter, while those in $P$. monodon reached $1 \mathrm{~mm}$; white spots were more readily seen when the carapace was removed (Fig. 2A,B). Under differential interference microscopy, the shapes of the white spots were different for the two species. The centers of the white spots in the carapace of $M$. rosenbergii were ring-shaped, about $0.1 \mathrm{~mm}$ in diameter and the spots extended outwards from the centers to form an irregular outer margin. The centers for $P$. monodon were about $20 \mu \mathrm{m}$ in diameter and the extensions were roughly circular with a collar $20-50 \mu \mathrm{m}$ in width at the outer margin (Fig. 2C,D). The color of the spots from the 2 species was also strikingly different, those from $M$. rosenbergii being mostly white, and those from $P$. monodon having radial lines of various colors.

\subsection{Detection of $W S B V$ in M. rosenbergii}

After the first PCR amplification step, the expected 1447-bp fragment was amplified in DNA samples prepared from WSBV infected $P$. monodon, but not from any $M$. rosenbergii sample. However, when the first amplification product was used as the template for the second PCR amplification, 22 of the $52 \mathrm{M}$. rosenbergii gave positive 

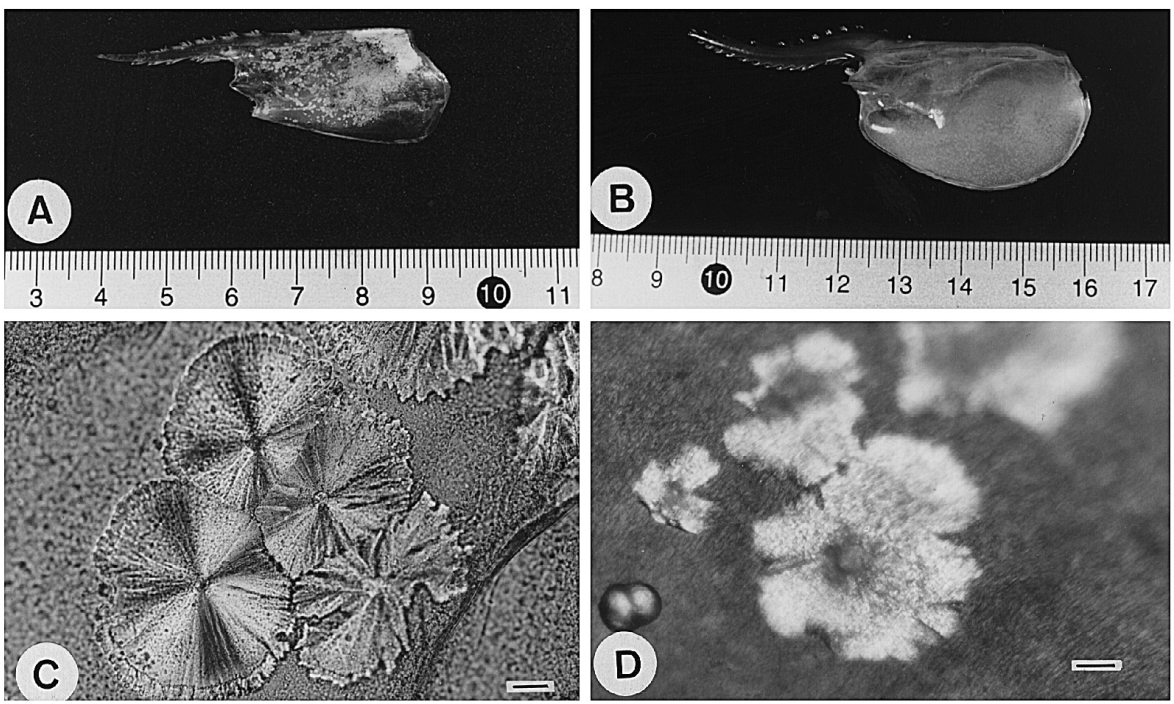

Fig. 2. Carapace removed from $P$. monodon (A) and M. rosenbergii (B) with white spot syndrome. Differential interference photo-micrograph of the white spots in the carapace of $P$. monodon (C) and $M$. rosenbergii (D). A,B: Scale bar: $1 \mathrm{~cm}$; C,D: Bar: $0.1 \mathrm{~mm}$.

indication for the presence of WSBV (19 juveniles and adults, 1 postlarva and 2 larvae; Table 1). Analysis of the second amplification products by electrophoresis showed that the fragments amplified from $M$. rosenbergii had the same mobility as the positive control P. monodon fragments at 941 bp (Fig. 3).

\subsection{Comparison of restriction profiles of PCR products}

When the products of two-step WSBV diagnostic PCR from positive samples were digested with HaeIII, HpaII, RsaI and Sau3AI restriction endonucleases, no differ-

Table 1

Results of two-step white spot baculovirus (WSBV) diagnostic PCR in M. rosenbergii collected from different culture farms (I-VI) in southern Taiwan

\begin{tabular}{lllllllll}
\hline WSBV diagnostic & & & & & & & & \\
\hline PCR & I & II & III & IV & V & & VI & Total \\
\cline { 6 - 8 } & & & & & & Postlarvae & Larvae & \\
\hline One-step PCR & $0 / 5$ & $0 / 10$ & $0 / 7$ & $0 / 18$ & $0 / 5$ & $0 / 2$ & $0 / 5$ & $0 / 52$ \\
Two-step PCR & $1 / 5$ & $7 / 10$ & $3 / 7$ & $6 / 18$ & $2 / 5$ & $1 / 2$ & $2 / 5$ & $22 / 52$ \\
\hline
\end{tabular}

Values represent the number of shrimp positive in the first or second step of PCR/number of shrimp examined. 

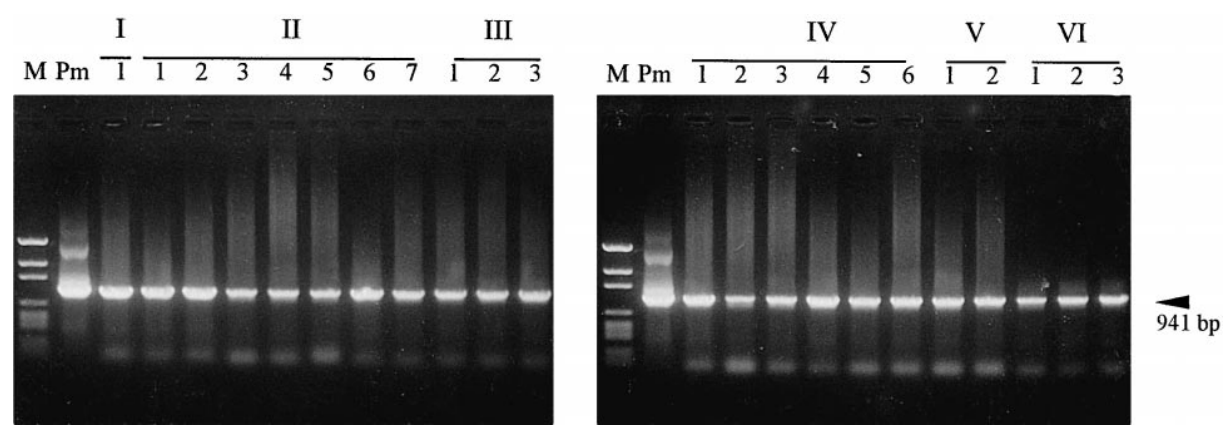

Fig. 3. PCR amplification of WSBV DNA fragments from templates prepared from specimens of $M$. rosenbergii collected from different culture farms in southern Taiwan. Farms I-V: juvenile and adult specimens, 2-40 g; Farm VI: Postlarva (1) and larvae (2,3); M: pGEM DNA size marker; Pm: WSBV infected P. monodon.

ences were observed in the profiles for P. monodon and M. rosenbergii (Fig. 4). The digestion fragments showed mobilities similar to those previously reported (Lo et al., 1996a). The result suggested that WSBVs found in P. monodon and M. rosenbergii were closely related.

\subsection{WSBV challenge in $M$. rosenbergii}

The dead larvae and postlarvae collected 48-h post-exposure to WSBV were subjected to one-step diagnostic PCR. When southern blot hybridization was performed with the WSBV probe specific to the internal region of the pms 146 fragment, 5 of the 8

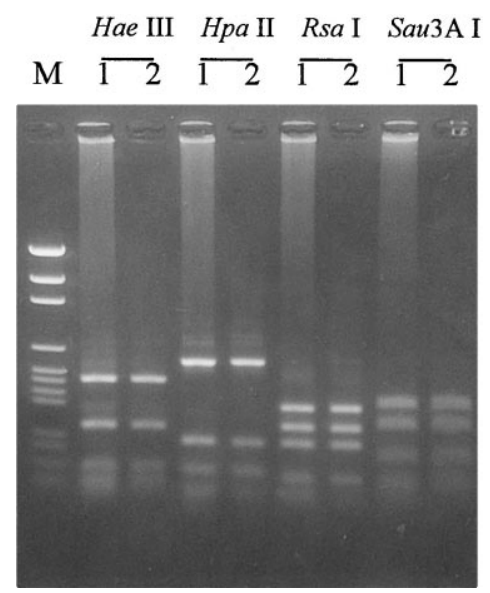

Fig. 4. Restriction enzyme profile of two-step WSBV PCR products amplified from P. monodon and M. rosenbergii. The products from two-step WSBV PCR positive samples were recovered by ethanol precipitation and further digested with HaeIII, HpaII, RsaI and Sau3AI restriction endonucleases. The fragments were analyzed by electrophoresis on $1.5 \%$ agarose gel containing ethidium bromide at a concentration of 0.5 $\mu \mathrm{g} / \mathrm{ml}$, and visualized by ultraviolet transillumination. M: pGEM DNA size marker, 1: P. monodon 2: $M$. rosenbergii. 


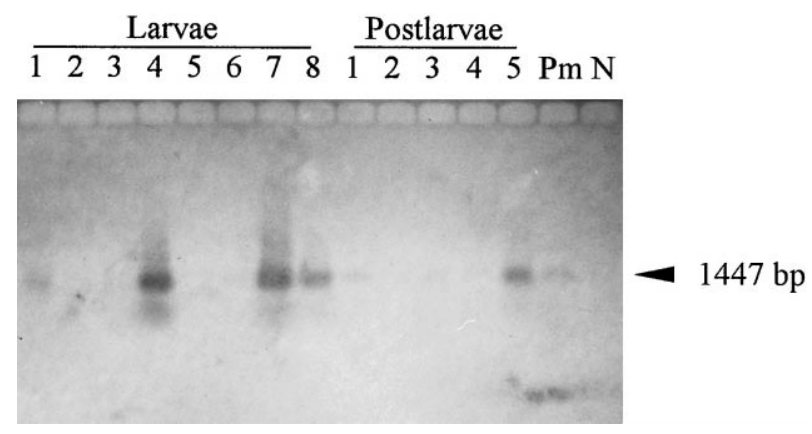

Fig. 5. Assessment of the extent of WSBV infection in 8 larvae and 5 postlarvae which died $48 \mathrm{~h}$ after exposure to a homogenate containing WSBV. The products from one-step PCR were analyzed by electrophoresis on a $1 \%$ agarose gel. This was followed by southern blot hybridization with DIG-labelled probe specific to a $941 \mathrm{bp}$ fragment of WSBV. Pm: WSBV infected P. monodon; N: template-free control reaction.

larvae samples and all of the 5 postlarvae samples tested positive. These samples were part of the treated groups (Fig. 5). The larvae showed stronger positive signals than the postlarvae, suggesting that infection was greater in the larvae.

\section{Discussion}

Until recently, very few viruses had been discovered in the giant freshwater prawn, $M$. rosenbergii. The first reported virus was parvo-like, and was observed in postlarval $M$. rosenbergii survivors of toxicity experiments. By histological observation it was presumptively diagnosed as hepatopancreatic parvo-like virus (HPV) (Anderson et al., 1990). The results of in situ hybridization with an HPV-specific probe, however, revealed that the HPV in $P$. chinesis and $M$. rosenbergii were not, after all, closely related (Lightner et al., 1994). The WSBV diagnostic PCR used here, on the other hand, shows that the same virus, WSBV, can infect and induce a similar syndrome in freshwater prawn and in marine shrimp.

The culture of $M$. rosenbergii has developed rapidly in some tropical areas. This species was originally considered less susceptible to diseases than marine shrimp. Nonetheless, a wide variety of diseases has occurred, including protozoal, bacterial, fungal and viral infections. New (1995) also reported problems arising from nutritional deficiencies or poor environmental conditions. Although M. rosenbergii is cultured in freshwater, its larvae develop in brackish water (about 6-15\%) which later move to fresh water to continue its development. There is often a greater incidence of disease during metamorphosis from larvae to postlarvae and during the postlarval nursery period. Since larvae of $M$. rosenbergii develop in a brackish water habitat close to marine shrimp, it is possible that viral agents of wild marine shrimp can also infect larvae of $M$. rosenbergii.

Although clinical signs were observed in juvenile and adult specimens of $M$. rosenbergii collected from farms and cultured in fresh water, WSBV could be detected 
only by two-step WSBV PCR. Despite being WSBV-positive, however, no mortalities were obviously attributable to WSBV. Meanwhile, the results of our challenge experiment suggest that the extent of infection was greater in larvae than in postlarvae. Evidently, infection by WSBV may vary in larval, postlarval, juvenile and adult stages of $M$. rosenbergii.

This study showed that $M$. rosenbergii is susceptible to WSBV. Although all of the larvae and postlarvae brought in by farmers for diagnosis had opaque musculature syndrome, only 3 out of 7 specimens were positive for WSBV even after two-step PCR (Table 1). Likewise, in the challenge tests, some specimens were PCR-positive but did not show opaque musculature syndrome and vice versa. This indicates that there is no clear relationship between WSBV and opaque musculature syndrome.

In P. monodon, it has already been shown that various tissues originating from both the mesoderm and the ectoderm are sites of initial WSBV infection, and that the cuticular epidermis, connective tissue and lymphoid organ are major attack sites (Chang et al., 1996). However, the details of the pathogenicity and virulence of WSBV in $M$. rosenbergii are still unclear, and the points of viral entry as well as the initial sites of the disease urgently need to be investigated.

\section{Acknowledgements}

This work was supported by grants from the Council of Agriculture and the National Science Council. We are indebted to Dr. Jung-Yaw Lin, Institute of Biochemistry, College of Medicine, National Taiwan University for his constructive suggestions, and access to databases. We thank Dr. I Chiu Liao, Director General, Taiwan Fisheries Research Institute (TFRI), and Mr. Paul Barlow for their helpful criticism of the manuscript.

\section{References}

Anderson, I.G., Law, A.T., Shariff, M., Nash, G., 1990. A parvo-like virus in the giant freshwater prawn, Macrobrachium rosenbergii. J. Invert. Pathol. 55, 447-449.

Cai, S., Huang, J., Wang, C., Song, X., Sun, X., Yu, J., Zhang, Y., Yang, C., 1995. Epidemiological studies on the explosive epidemic disease of prawn in 1993-1994. J. Fish. China 19, 112-117.

Chang, P.S., Lo, C.F., Wang, Y.C., Kou, G.H., 1996. Identification of white spot syndrome associated baculovirus (WSBV) target organs in shrimp, Penaeus monodon, by in situ hybridization. Dis. Aquat. Org. 27, 131-139.

Chou, H.Y., Huang, C.Y., Wang, C.H., Chiang, H.C., Lo, C.F., 1995. Pathogenicity of a baculovirus infection causing white spot syndrome in cultured penaeid shrimp in Taiwan. Dis. Aquat. Org. 23, 165-173.

Fisheries Yearbook of Taiwan Area, 1992-1995. Taiwan Fisheries Bureau, Department of Agriculture and Forestry, Provincial Government of Taiwan, in Chinese.

Inouye, K., Miwa, S., Oseko, N., Nakano, H., Kimura, T., 1994. Mass mortalities of cultured kuruma shrimp, Penaeus japonicus, in Japan in 1993: electron microscopic evidence of the causative virus. Fish Pathol. 29, $149-158$, in Japanese.

Lightner, D.V., Redman, R.M., Poulos, B.T., Mari, J.L., Shariff, M., 1994. Distinction of HPV-type viruses in Penaeus chinesis and Macrobrachium rosenbergii using a DNA probe. Asian Fish. Sci. 7, 267-272. 
Lightner, D.V., 1996. A Handbook of Pathology and Diagnostic Procedures for Disease of Penaeid Shrimp. World Aquaculture Soc., Baton Rouge, Section 3.11.

Lo, C.F., Leu, J.H., Ho, C.H., Chen, C.H., Peng, S.E., Chen, Y.T., Chou, C.M., Yeh, P.Y., Huang, C.J., Chou, H.Y., Wang, C.H., Kou, G.H., 1996a. Detection of baculovirus associated with white spot syndrome (WSBV) in penaeid shrimps using polymerase chain reaction. Dis. Aquat. Org. 25, 133-141.

Lo, C.F., Ho, C.H., Peng, S.E., Chen, C.H., Hsu, H.C., Chiu, Y.L., Chang, C.F., Liu, K.F., Su, M.S., Wang, C.H., Kou, G.H., 1996b. White spot syndrome baculovirus (WSBV) detected in cultured and captured shrimp, crabs and other arthropods. Dis. Aquat. Org. 27, 215-225.

Momoyama, K., Hiraoka, M., Nakano, H., Koube, H., Inouye, K., Oseka, N., 1994. Mass mortalities of cultured kuruma shrimp, Penaeus japonicus, in Japan in 1993: histopathological study. Fish Pathol. 29, $141-148$, in Japanese.

Nakano, H., Koube, H., Umezawa, S., Momoyama, K., Hiraoka, M., Inouye, K., Oseko, N., 1994. Mass mortalities of cultured kuruma shrimp, Penaeus japonicus, in Japan in 1993: epizootiological survey and infection trials. Fish Pathol. 29, 135-139, in Japanese.

New, M.B., 1995. Status of freshwater prawn farming: a review. Aquacult. Res. 26 (1), 1-54.

Sambrook, J., Fritsch, E.F., Maniatis, T., 1989. Molecular Cloning, A Laboratory Manual, 2nd edn. Cold Spring Harbor Laboratory Press, Cold Spring Harbor, New York.

Takahashi, Y., Itami, T., Kondom, M., Maeda, M., Fujii, R., Tomonaga, S., Supamattaya, K., Boonyaratpalin, S., 1994. Electron microscopic evidence of bacilliform virus infection in Kuruma shrimp (Penaeus japonicus). Fish Pathol. 29, 21-125.

Wang, C.H., Lo, C.F., Leu, J.H., Chou, C.M., Yeh, P.Y., Chou, H.Y., Tung, M.C., Chang, C.F., Su, M.S., Kou, G.H., 1995. Purification and genomic analysis of baculovirus associated with white spot syndrome (WSBV) of Penaeus monodon. Dis. Aquat. Org. 23, 239-242.

Wongteerasupaya, C., Vickers, J.E., Sriurairatana, S., Nash, G.L., Akarajamorn, A., Boonsaeng, V., Panyim, S., Tassanakajon, A., Withyachumnarnkul, B., Flegel, T.W., 1995. A non-occluded, systemic baculovirus that occurs in cells of ectodermal and mesodermal origin and causes high mortality in the black tiger prawn Penaeus monodon. Dis. Aquat. Org. 21, 69-77. 